Beyond the Borderlands 



\section{Beyond the Borderlands}

M I GR A T I O N A N D B EL O NGING I N

THE U NITED STATES A N D M EXICO

DE B R A L A T T A N Z I S H U T IK A

甲

UNIVERSITY OF CALIFORNIA PRES

Berkeley Los Angeles London 
University of California Press, one of the most distinguished university presses in the United States, enriches lives around the world by advancing scholarship in the humanities, social sciences, and natural sciences. Its activities are supported by the UC Press Foundation and by philanthropic contributions from individuals and institutions. For more information, visit www.ucpress.edu.

University of California Press

Berkeley and Los Angeles, California

University of California Press, Ltd.

London, England

(C) 2011 by The Regents of the University of California

Library of Congress Cataloging-in-Publication Data

Lattanzi Shutika, Debra, 1964-

Beyond the borderlands : migration and belonging in the U.S. and Mexico / Debra Lattanzi Shutika.

p. $\mathrm{cm}$.

Includes bibliographical references and index.

ISBN 978-o-520-26958-3 (cloth) — ISBN 978-o-520-26959-o (pbk.)

1. Mexican Americans-Cultural assimilation-Pennsylvania-

Kennett Square. 2. Mexican Americans-Pennsylvania-Kennett Square-Ethnic identity. 3. Kennett Square (Pa.)—Ethnic relations. 4. Guanajuato (Mexico : State) -Emigration and immigration-Social aspects. I. Title.

F159.K26S58 2011

305.8968' 72074813 -dc22

2010053180

Manufactured in the United States of America

$\begin{array}{llllllllll}20 & 19 & 18 & 17 & 16 & 15 & 14 & 13 & 12 & 11\end{array}$

$\begin{array}{llllllllll}10 & 9 & 8 & 7 & 6 & 5 & 4 & 3 & 2 & 1\end{array}$

This book is printed on Cascades Enviro 100, a 100\% post-consumer waste, recycled, de-inked fiber. FSC recycled certified and processed chlorine free. It is acid free, Ecologo certified, and manufactured by BioGas energy. 